\title{
Introduction to Leadership, Populism, and Resistance
}

\section{Kristin M.S. Bezio and George R. Goethals}

In the United States, the United Kingdom, and many other places around the world, but particularly in Europe, the second decade of the twenty-first century has seen an unprecedented rise in right-wing populism. This nativist, nationalist, and exclusionary politics is not new; however, its widespread success is. It spread across the Atlantic Ocean in 2016 from Brexit to the election of Donald Trump. The new US president added authoritarianism to the already tumultuous brew of nativism, nationalism, and exclusion. While this mix of qualities had never previously defined the American presidency, it is not a recent construction. It was seen, of course, in Nazi Germany in the 1930s and 1940 s, and it is on display today around the world in many places, including Australia, Hungary, Turkey, and the Philippines.

Defining populism is tricky. For one thing, it comes in left-wing as well as right-wing configurations and has taken many different outward forms across the centuries, although its fundamentals remain eerily consistent. These fundamental attributes include opposition and resistance to elites by common citizens based on feelings of being shortchanged materially and disdained psychologically, as well as a sense of powerlessness. When supporters of populist politics gain power, thereby becoming the establishment themselves, using the term populists to describe them doesn't quite work anymore. However, whether populists are in power looking out or out of power looking in, whether they represent the right or the left, we can note several qualities that consistently define them. One is a tendency to view the world in us versus them, in-group versus out-group, dichotomies. It is not an inclusive outlook. Closely related to that view of the world is significant hostility toward outsiders. Some, but not all, of this reflects the feeling that members of the out-group look down on them. Even when they hold and exercise political power, populists often feel that cultural elites disdain them, and thereby earn their hostility. Yet whether or not they feel looked down on by the out-group, they gain self-esteem through positive in-group social identity and out-group derogation.

Those who adhere to populist exclusionism make specific claims of types of national identity predicated on specific understandings of nativism or 
demography - for instance, the presumption or assertion that Americans are born within the United States, are white, and are Christian (which ignores multiple historical truths, including the fact that those indigenous to the territory occupied by the United States are not white). Such assertions often lead to segregationist and separatist policies and can contribute to increased violence against and oppression of those deemed ineligible or unworthy of fitting within the in-group. For instance, the United States has seen a substantial increase (of 226 percent) in hate crimes targeting immigrants and people of color since 2016 in cities where Donald Trump held a campaign rally (Choi, 2019), suggesting that the populist rhetoric of the campaign increased in-group, out-group salience and exacerbated exclusion-related crime (Feinberg et al., 2019).

An additional feature - particularly of today's populism, compared to, say, the populism of William Jennings Bryan in the late 1890s and early 1900s or Jeffersonian Republicans of the early 1800 s - is authoritarian and essentially anti-democratic leadership. The combination of self-esteem based on out-group derogation and authoritarian leadership reminds us of insights from the 1950 publication of The Authoritarian Personality and its well-known F scale, F standing for the next-to-last word in the full title of the measure: "The Implicit Antidemocratic Trends or Potentiality for Fascism (F) Scale" (Adorno et al., 1950). Its authors saw status anxiety and the need for positive self-esteem as the underlying dynamic leading to the appeal of authoritarian leadership that draws sharp lines between the good and the bad, the moral and the immoral, and the strong and the weak.

It is also important to note that status anxiety or, more generally, fear produced by perceived crisis, makes way for charismatic leadership. Max Weber (1947, p. 48) viewed charismatic leadership as arising during unsettled times when followers give complete devotion to leaders who are seen as possessing "supernatural, superhuman, or at least specifically exceptional qualities" that can save followers from disaster. Weber's description of followers' devotion to charismatic leaders follows Freud's account of people's irrational love for despotic leaders who care little about followers other than how they might advance the leader's own agenda. Needless to say, charismatic leaders, given essentially carte blanche by followers in populist movements, often become authoritarian, if they are not so already. Adolph Hitler and Donald Trump (among others) once again illustrate the point.

From a historical perspective, populism has ties to images of jack-booted thugs, "disappearances" facilitated by governments, internment camps, and other markers of hyper-authoritarian oppression. What is most interesting about these images is that they can serve to represent the elite power against which populism arose almost as frequently as they represent populist regimes. Margaret Canovan (1999, p. 3) defines populism in historical terms as "an 
appeal to 'the people' against both the established structure of power and the dominant ideas and values of the society." Despite the fact that populists are de facto if not de jure anti-democratic, they often "see themselves as true democrats, voicing popular grievances and opinions systematically ignored by governments, mainstream parties and the media" (Canovan, 1999, p. 2). Populism thus claims to be acting in the interests "of the people," but has a highly exclusionary, nativistic, and nationalistic definition of those "people" (and those in the out-group who do not belong in the category of "the people").

Furthermore, it is important to recognize the threat posed to democracy by an anti-democratic movement that purports to be the very thing (democratic) it operates against. It is also important to understand that populist opposition exists not only in terms of elites and government power holders, but also against "opinion-formers in the academy and the media" (Canovan, 1999, p. 3). In Western countries such as the United Kingdom and the United States, Canovan (1999, p. 4) notes, "Where . . . elite political culture is strongly imbued with liberal values of individualism, internationalism, multiculturalism, permissiveness and belief in progress, populism is bound to involve more or less resistance to these." As such, populism is, in and of itself, both a force of resistance for some and a force to be resisted for others.

It can be helpful to examine the political origins of the United States in medieval and early modern England and note the precursors of populism embedded within limited participatory monarchy. In Parliament-specifically, in the elected positions of the House of Commons - we find the ancestry of the United States' bicameral legislative branch, as well as the early foundations of the United Kingdom's present-day constitutional monarchy. The medieval underpinnings of the House of Commons as a representative branch of government can be traced back not only to the Model Parliament of 1295 or the Magna Carta of 1215, but also to the so-termed Anglo-Saxon Magna Carta of the Anglo-Saxon Chronicle, dating to 1014 under King Æthelred (the Unready) (Bezio, 2015, p. 10; Swanton, 1998, p. 145). While there was yet no elected body in England in 1014 (that would not appear until 1295 and the Model Parliament), the uprising which led to the creation of the agreement cited in the Chronicle has many of the elements that make up later medieval, early modern, modern, and contemporary populist movements.

Although most uprisings in medieval and early modern Europe were not inherently populist, those that rejected social elitism in favor of an us versus them exclusionary mentality are among those that made the most significant historical and ideological impact. For instance, the populist Puritan movement, which became, in the seventeenth century, the English Civil War, culminated in a monarch's execution ratified by the very government he was meant to head. The 1649 death of Charles I can be traced back to a populist myth perpetuated by members of the Parliamentarian faction during the war; they alleged 
that "Before 1066 the Anglo-Saxon inhabitants," the so-called "natives" of England, "lived as free and equal citizens, governing themselves" (Hill, 1958 [1970], p. 57). It was not until the arrival of William I in 1066 that the "Norman Yoke," as it came to be called, was settled on the shoulders of these natives and bent them to the will of a foreign elite. Throughout the mid-seventeenth century, the idea of the Norman Yoke became a populist touchstone invoked by the Parliamentarians seeking to overthrow their Royalist counterparts, the ostensible inheritors (both genetically and ideologically) of William of Normandy. Similar elements of populism lay at the root of rebellions and uprisings across Europe, including in the French Wars of Religion during the sixteenth century and the Spanish Reconquista and expulsion of Moriscos into the seventeenth century, as will be mentioned later in this volume.

This medieval and early modern populist foundation was not left behind by Europeans who settled in the United States, nor was it absent among the Founders who broke from England in the eighteenth century, as several chapters will note. Even during the 1920s and 1930s - long after the United States had been thoroughly established-“America seemed on the cusp of a violent break from ... democratic capitalism" (Meacham, 2018, p. 138). In fact, during the summer of 1932, before his election to the presidency, Governor Franklin D. Roosevelt of New York worried about a dangerous populist left under the influence of Huey Long of Louisiana and a right-wing version offered by General Douglas MacArthur (Meacham, 2018, p. 138).

It was also populism which launched Billy James Hargis's Operation Midnight Ride in 1963 under the sponsorship of the Christian Crusade, considered "America's largest anti-Communist group" (Issenberg, 2018, p. 40) during the Civil Rights era. The organization, Issenberg (2018, pp. 42-3) explains, was part of a swath of "conservative thought" that "had been swirling through American culture ever since FDR's New Deal sparked opposition from people wary of government intrusion into the free market." One of Hargis's main complaints that encapsulates populist exclusionary politics was the idea that "These wealthy people" - those who did not donate to the Christian Crusade - "are scared to be associated with a bunch of crackpots and Nazis - if you want to know the truth of the matter, that's it . . I think the capitalists of this country ought to be ashamed of themselves for the little they have done to protect freedom" (quoted in Issenberg, 2018, pp. 40-42). The attitude that the elites (in this case, the wealthy) have abandoned the fundamentals on which the United States was founded is one perpetuated across both right- and left-wing populism and situates populists as the protectors - as with the myth of the Norman Yoke in seventeenth-century England - of a nationalist and "nativist" identity.

As we can see, populism, as a manifestation of anti-elitist, exclusivist, and often nationalist and nativist ideologies, is neither new nor exclusive to the 
United States. It appears and has appeared around the world in situations of crisis (or perceived crisis) in which some portion of the population believes that its foundational beliefs are being threatened by a (perceived) elite, defined by wealth, education, or participation in the establishment, and is often characterized by charismatic, authoritarian leadership. Populism has led to both successful and failed rebellions and to both social and political progress and stagnation. In short, although what makes populism populism is a particular combination of exclusion, nativism/nationalism, and opposition to elitism, the components that make up those attributes shift to reflect the particular places and times in which populism has manifested.

This volume seeks to disentangle the mysteries of populism, the resistance that it brings to the power of elites, and the opposition that more democratic, inclusive politics brings to bear on it. We begin in Part I with Paul Sanders's chapter, which seeks to capture the theoretical essence of populism in both historical and contemporary contexts. The next four chapters, comprising Part II, explore populism, or contrasting pluralistic politics, in historical perspective. The first two look at political conflict in the sixteenth and seventeenth centuries, in England and in Spain and Latin America. Kristin Bezio traces the similarities between anti-Catholic sentiment during the Elizabethan era and modern Western Islamophobia, while Ernesto Semán traces the emergence of the idea of charismatic caudillos from Spain to Latin America and how that style of leadership fits populist leadership elsewhere. Nathan Harter and Cydney Clark explore Shays's Rebellion in 1786 in the United States and its role in provoking the Constitutional Convention in 1787 and the new nation's formation of a strong central government. Finally, Julian Hayter explains how pluralist, as opposed to populist, politics during the Civil Rights era led to the 1964 Civil Rights Act and the 1965 Voting Rights Act.

Part III examines the complex relationship between the media and populist movements, including a history of conflict and challenge, as well as the ways in which social media have shifted both populism and resistance to it. Hayley Gray-Hoehn examines the history of leader use of media from early forms of print culture, through broadcast media, and into the modern age of the internet. Allison Archer follows a similar historical through-line but focuses specifically on the frequently hostile relationship between media producers and populist leaders like Richard Nixon and Donald Trump. Kimberly Yost examines the ways in which social media - specifically, Twitter-has been used as a site of resistance to contemporary populism.

In Part IV, the chapters present fundamental problems created by contemporary populism and seek to address those problems. Scott T. Allison, George R. Goethals, and Smaragda P. Spyrou examine Donald Trump as a populist figurehead and puer aeternus ("eternal boy") and provide possible means of encouraging leader maturity. Tom Shields and Kate Cassada examine the 
impact of recent exclusionary, anti-immigrant politics on the US education system and address the complex difficulties of acting as a moral leader within an educational system so deeply impacted by these exclusionary policies. Also addressing education, Thad Williamson offers a hopeful narrative about educating future citizens and leaders for the critical work of just living and civic participation by educating students to be responsible participants in a truly democratic system - in short, teaching them how they can help save democracy. From this hopeful note, Ken Ruscio's final chapter, in Part V, concludes with a historic overview of the importance of virtue in leadership and suggests that "one of the most important, if also one of the most forgotten, of those virtues is humility" and that "Good democratic leadership depends upon it."

Together, this volume offers a broad, interdisciplinary view of the problems posed by populism and calls for a recognition of the importance of resisting populist nationalism, nativism, and exclusionism in the maintenance of democratic ideals. By examining the ways in which populism has historically manifested, the ways in which it currently challenges our modern democratic structures, and the possible means by which we can resist its influence, this volume seeks to provide both critical understanding of and insight into our modern "crisis in leadership."

\section{REFERENCES}

Adorno, T.W., E. Frenkel-Brunswik, D.J. Levinson, and R.N. Sanford (1950), The Authoritarian Personality, New York: Harper and Row.

Bezio, K.M.S. (2015), Staging Power in Tudor and Stuart English History Plays: History, Political Thought, and the Redefinition of Sovereignty, Farnham: Ashgate Publishing Limited.

Canovan, M. (1999), "Trust the people! Populism and the two faces of democracy," Political Studies 47 (1), 2-16.

Choi, D. (2019), "Hate crimes increased $226 \%$ in places Trump held a campaign rally in 2016, study claims," Business Insider, 23 March.

Feinberg, A., R. Branton, and V. Martinez-Ebers (2019), "Counties that hosted a 2016 Trump rally saw a 226 percent increase in hate crimes," The Washington Post, 22 March.

Hill, C. (1958), Puritanism \& Revolution: The English Revolution of the 17th Century, third printing (1970), New York: Schocken Books.

Issenberg, S. (2018), "Barnstorming America: How a fiery preacher and a maverick Army general took a wild cross-country ride that launched the populist conservative movement," Smithsonian 49, 40-51.

Meacham, J. (2018), The Soul of America: The Battle for Our Better Angels, New York: Random House.

Swanton, M. (ed.) (1998), The Anglo-Saxon Chronicle, New York: Routledge.

Weber, M. (1947), The Theory of Social and Economic Organization, New York: Free Press. 